\title{
GREATEST PRINTING OFFICE IN THE WORLD.
}

Hon. Frank W. Palmer is still remembered in great kindness by thousands of people in Iowa, though it is thirty years since he removed from Des Moines to Chicago. A brief sketch of his life and public services was given on page 403, Vol. IV, 3d series of THE Annals. Iowa readers will remember that he was state printer and editor of The Iowa State Register from 1861 to 1868 . He served as a member of congress from the fifth district of Iowa from 1869 to 1873 . Removing to Chicago in the latter year he became editor-in-chief of The Inter Ocean, and also served eight and one-fourth years as postmaster of that city. President Harrison appointed him government printer, and he was reappointed by President McKinley. The building in which that ancient printing office was located was an old, dilapidated affair which had become wholly inadequate for the constantly increasing needs of the government. Mr. Palmer brought the matter before congress and secured an appropriation of $\$ 2,429,000$ with authority to erect a new building. This has just been completed. William E. Curtis, the distinguished journalist, traveler, and author, made it the subject of one of his exhaustive letters which appeared in The Chicago Record-Herald of May 25, 1903. From this we copy the following paragraphs, portraying the magnitude of this great enterprise, which was projected and brought to a successful conclusion by an old Iowan:

The government of the United States has in Washington the greatest printing office in the world, double the size of any other. It is under the management of Frank W. Palmer, formerly editor of The Inter Ocean and for eight years postmaster at Chicago. It had been housed in a dangerous and dilapidated old barracks for many years, which was condemned as unsafe by the building inspectors and sanitary authorities. Mr. Palmer has been compelled to prop up the walls with timbers and place heavy beams at frequent intervals to support the floors, but finally congress became sensib!e of its requirements and appropriated $\$ 2,429,000$, which bas been expended during the last four years in the erection of what is almost a perfect building for its purpose. The work of construction is nearly completed. New oak cases for typo and "sorts" and the thousand and one lit- 
tle tricks essential to the printer's trade are being put in place, and before congress again assembles this great branch of the gorernment's business will be well established in its new home, with conveniences, equipments and machinery surpassing everything that was ever provided for a printing office before.

The work has been done under the direction of Mr. Palmer. James G. Hill of this city is the architect, Captain J. S. Sewell of the engineer corps has been superintendent of construction, and Homer $K$. Collins, chief 'engineer of the public printing office, and W. H. Tapley, chief electrician, have had immediate charge. To them Mr. Palmer ascribes the largest degree of credit for the perfection of the new plant. They have been assisted by Captain $H$. T. Brian, formerly foreman of printing and now chief clerk; P. J. Bryne, foreman of the binding department, and D. J. O'Leary, foreman of press work, all of whom have made eminent reputations in their line of business.

The high efficiency of the office is largely due to the executive ability, tact and high sense of the fitness of things on the part of the public printer. The office used to be the center of scandal and corruption, but it has been one of the cleanest and most economical and satisfactory branches of the government since Mr. Palmer took hold. He unselfishly gives eredit to the gentlemen I have named and others equally loyal and efficient who might also be named.

The new printing office will have a floor space of 619,700 square feet, which is equivalent to about fourteen acres, or four ordinary city blocks, which is divided into seven floors almost without partitions. Printers need a good deal of light, and it is provided for them by 1,500 windows. One-third of all the wall space is glass, and, in order that this light may not be lost, the walls of the rooms are lined with white enameled bricks which can be washed like a bath tub or the marble steps of the houses in Philadelphia. The building is absolutely fireproof, or as near fireproof as any building can be. It is also as substantial as possible, and its walls are built like those of the fortress because type is heavy and printing presses cause considerable vibration, and it would be unfortunate to have the roof and the walls cave in and bury 3,957 American citizens under material and machinery that is intended only for the dissemination of intelligence.

The engineers provided for floors to sustain a load of $85,000,000$ pounds, if any one can comprebend what that means, and it is, of course, very much in excess of any weight that could possibly be placed upon it. The outside walls are three feet thick, and to construct them $10,000,000$ brick were required. Inclosed within them is a steel frame work weighing about $12,000,000$ pounds, which is heavier, perhaps, than the frame of any other building in the country. Every care was taken to secure the greatest possible solidity of construction. The columns, beams, girders, channels and plates were not made of ordinary steel stock, but were forged to order, and the steel work is so protected that in case of heat being generated by the burning of any material that might be placed in the building, its strength will not be affected by warping. 
A complete system of telephones has been installed; so that the foreman of every department can communicate with the chiefs of his division, and by lifting a receiver to his ear Mr. Palmer may know instantly what is going on in any part of his establishment. In order to provide for all this several miles of wire have been used, enough, they tell, to go twice around the City of Washington. Vaults have been constructed at convenient places on the different floors for the storage of standing type, stereotype plates and printed documents of a secret and confidential character, such as messages of the president, reports of his secretaries, treaties, conventions, reports of congressional committees, and other documents, until it is time to give them to the public.

There are enormous storerooms for the stock of material kept on hand, which is probably greater in amount than can be found in any similar establishment in the world. In the regular course of business the printers use about fifteen tons of paper a day, and in the cases are more than 2,000,000 pounds of ordinary type.

There are 3,957 employes upon the pay roll of the government printing office.

The government of the United States does more printing and publishes more documents than any other nation in the world, and last year the cost of this branch of the service reached $\$ 5,8 \pm 8,453.08$.

An Event transpired in the little village of Clermont, Fayette county, Iowa, on the 19 th day of June last, to which we can devote but a brief paragraph at this time, but which we hope may be fully described in some future number of THE Annals, with ample and appropriate illustrations. We refer to the unveiling and dedication of two bronze statues, one of Abraham Lincoln, and the other of Col. D. B. Henderson. These statues were the generous and patriotic gift of ExGovernor William LaRrabeE, whose hospitable home is in the outskirts of that village. This is the first instance in Iowa in which a statue has been erected to Abraham Lincoln, and few men while still living have received such an honor as this which has been so appropriately and happily paid to Col. Heñderson. (Prof. S. F. B. Morse, inventor of the telegraph, was present and saw his bronze statue unveiled in Central Park, New York City, June 10, 1871.) Clermont was already classic ground, as the residence of Gov. WILLIAM LARRABEE; it becomes doubly so by the erection of these magnificent works of art. 
Copyright of Annals of Iowa is the property of State of Iowa, by \& through the State Historical Society of Iowa and its content may not be copied or emailed to multiple sites or posted to a listserv without the copyright holder's express written permission. However, users may print, download, or email articles for individual use. 